\title{
Perception of the Consumer Community on Traditional Herbal Drink of Ngadirgo Semarang
}

\author{
Eka Yuniati ${ }^{1, *}$ Fadly Husain ${ }^{2}$, Antari Ayuning Arsi ${ }^{3,}$ Harto Wicaksono ${ }^{4}$
}

\author{
1,2,3,4 Department of Sociology and Anthropology, Faculty of Social Sciences, Universitas Negeri Semarang \\ *Corresponding author. Email: ekayuniati88@students.unnes.ac.id
}

\begin{abstract}
Jamu is a traditional herbal drink that is still in demand by many people until now. Traditional herbal medicine has various benefits including prevention, maintenance, and healing of diseases. This research was conducted to explore the consumer's perception about the traditional herbal drink Ngadirgo Semarang. This study used a qualitative approach, with 21 informants consisting of 19 female informants and 2 male informants. The data collection techniques are carried out by observation, interviews, and documentation. The results showed that there were several perceptions in society. The consumer's perception about traditional herbal drinks also varied, starting from the reasons, the taste, and the experience of consuming herbal drinks. Consumers have various reasons to consume traditional herbal drinks such as based on the perceived disease, side effects of herbal drink, the effectiveness of drinking herbal drink, and the low price. From this research, it can also be seen how the public's perception of the traditional herbal drink Ngadirgo Semarang that they consume, such as the flavor and texture of herbal drink, serving method, and the experience of consuming traditional herbal drink. The consumers of traditional herbal drinks transmit their knowledge from generation to generation.
\end{abstract}

Keywords: jamu, herbal drink, traditional medicine.

\section{INTRODUCTION}

In the midst of modern medicine which continues to experience very rapid development, traditional medicine continues to show its existence. Traditional herbal medicine is made using natural ingredients [1]. According to WHO [2], the use of traditional medicine is highly recommended. In 1988, traditional herbal medicine is claimed to be an area for potential growth programs. Traditional herbal medicine and health care practitioners continue to be developed in line with the needs of the community to provide alternative health services. WHO notes that jamu is a traditional herbal drink from Indonesian that has been practiced for centuries and passed down from generation to generation health, maintenance and treatment purposes. Until 1955, rules regarding traditional medicine and doctor as health nurses were regulated by the Ministry of Health of the Republic of Indonesia in Law Number 36 of 2009 concerning Health [3].

Perception is very determining if someone is consuming or not consuming herbal drink. This perception really needs to be known by the public with increasing the popularity of traditional medicine, especially in Indonesia [4]. Perception is a process of introduction or identification using the five senses. The impression a person receives depends on the experience he received through the process of thinking and learning. This is influenced by factors both from within and outside the individual [5]. The public perception about traditional herbal drink Ngadirgo Semarang in this study is varied. This research looks from various perspectives, such as taste, price, and other aspects. In addition, this research also wants to know the reason why people consume Ngadirgo Semarang traditional herbal drinks. Therefore, from this research can see the difference in the perceptions of the consumer community regarding traditional herbal drinks Ngadirgo Semarang.

Each region, especially in Indonesia, has different treatment methods. Traditional medicine has a connection with traditional herbal drink, because it's a form of traditional medicine. Some of the research results that discuss traditional medicine can be seen as follows. People consuming traditional herbal drinks cannot be separated from their decision or background. A study conducted by Jennifer \& Saptutyningsih [6], claimed that a person's decision to consume traditional herbal drink is influenced by 
several factors, including culture, family, relatives, reference groups, friends and psychological factors. In addition, Torri [7] also conducted research on traditional herbal drinks in Yogyakarta. Torri's research results show that traditional herbal drink is also considered to have relatively small side effects and does not even cause negative effects on body health, if used appropriately. Instead treatment is traditionally considered an effective effort to improve health. As in the consumer society traditional herbal drink Ngadirgo Semarang.

The purpose of this research was to find out and explore the perception of the consumer community about traditional herbal drinks of Ngadirgo Semarang.

\section{METHODS}

This study used a qualitative approach to understand the phenomenon experienced based on the views of the participants of a problem that occurs and described in the form of words and language [8][9]. This research tried to explore the perception of the consumer community about traditional herbal drinks of Ngadirgo Semarang. The number of informants in this study were 21 informants consisting of 19 females and 2 males. Data collection techniques carried out by observation, interviews, and documentation.

\section{RESULT AND DISCUSSION}

To explore and see the perception of the consumer community about traditional herbal drink Ngadirgo Semarang, the author conducted interviews with 21 key informants. The results of the research were classified into 3 parts, there are the reasons for consumers choosing traditional herbal drink of Ngadirgo Semarang, consumer tastes related to traditional herbal drink, and consumer perceptions about the making traditional herbal drink. The following is an explanation regarding the points above.

\subsection{Reasons Consumers Choosing Traditional Herbal Drink as Alternative Medicine}

Traditional herbal drinks are widely consumed by people as an alternative treatment. Various complaints of disease are healed by drinking traditional herbal medicine. People choose and consume traditional herbal medicine for several reasons. Based on research conducted on consumer informants of traditional herbal drink, there are several reasons that cause consumers to choose and buy traditional herbal here.

\subsubsection{Based On Disease.}

Consumers have different complaints according to the disease. From the identification complaints, consumers consider choosing the type of herbal drink for the disease. Complaints that are usually felt by the consumer community include aches, colds, and so on. The consumer communities usually tell these complaints to herbal drink sellers. Then the herbal drink seller will provide the herbal medicine according to the complaint. However, there are some consumers who choose or request the type of herbal drink they want, without asking the seller.

\subsubsection{Side Effects Of Traditional Herbal Drink.}

Traditional herbal drink as an alternative medicine is made with natural ingredients. Traditional herbal drink is considered safer than herbal medicine sachets herbal medicine. This affects people's interest in consuming traditional herbal drinks rather than sachets. The community believes that natural herbal medicine does not cause bad effects that can harm to the body. The herbs consumed are efficacious for the prevention and cure of diseases, such as aches, rheumatism, gout, and so on.

\subsubsection{Efficacy Of Traditional Herbal Drink.}

The herbal drink needed for consumers is adjusted to the complaints they feel. Usually there will be a reaction that is felt by consumers. Consumers say that traditional herbal drinks are the same as suggestions. If consumers believe that herbal drink will cure diseases, then it will function to heal, and vice versa. The effectiveness of herbal drinks is also felt by pregnant women. A pregnant woman usually consumes herbal drinks after giving birth. It is consumed to improve the health of mother and baby, and also increase milk production. They consume various kinds of herbal drinks, both traditional herbal drinks and herbal medicine sachets, so it seems that the effectiveness of herbal drinks has made many people choose it as an alternative medicine.

\subsubsection{Low Prices}

Price is one of the reasons people buy traditional herbal drinks. The price of herbal drinks is very affordable. Prices for herbal drinks start from Rp 2,000 - Rp 2,500 for plastic and glass sized. If in a

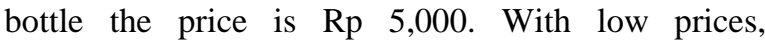
consumers get extraordinary benefits from consuming traditional herbal drinks. 


\subsubsection{Experience of Consuming Herbal Drink}

Based on interviews with informants, it can be seen in 3 parts. First, the experience of consuming for a long time. The influence of the socialization given by parents to children affects someone consuming traditional herbal drinks. Some people have been consuming traditional herbal drinks since they were a child. Second, the experience of consuming traditional herbal drinks after giving birth. According to the village community, the nutritional needs of mothers after childbirth are supported by traditional herbal drink. There are special ingredients that are consumed by mothers after childbirth, such as Nyonya Meneer and Sidomuncul. Third, the habit of subscribing to herbal medicine. From the habit of people who subscribe to herbal drinks, it causes some people indirectly dependent on herbal drinks. Many people then regularly consume herbal drinks. People usually consume herbal drinks according to the seller's time in selling herbal drinks. Based on observations, the selling time of the traditional herbal drinks Ngadirgo Semarang can be seen as follows.

Table 1. Time to Selling of Traditional Herbal Drink Ngadirgo Semarang

\begin{tabular}{|c|c|c|c|c|}
\hline No & Place & Seller & Time & Duration \\
\hline 1 & $\begin{array}{l}\text { Mijen Market, Mijen Sub- } \\
\text { district, Semarang City }\end{array}$ & Ms. Rianti & Tuesday until Sunday & $08.00-12.00$ \\
\hline 2 & $\begin{array}{l}\text { Tampingan Village, Boja Sub- } \\
\text { district, Kendal Regency }\end{array}$ & Ms. Sutiyah & $\begin{array}{l}\text { Tuseday, Thrusday, } \\
\text { Saturday }\end{array}$ & $07.00-09.00$ \\
\hline 3 & $\begin{array}{c}\text { Limbangan Market, Krajan } \\
\text { Village, Limbangan Sub-district, } \\
\text { Kendal Regency }\end{array}$ & Ms. Sukarti & $\begin{array}{l}\text { Monday, Wednesday, } \\
\text { Friday }\end{array}$ & $10.00-12.00$ \\
\hline 4 & $\begin{array}{l}\text { Industrial Area in Candi } \\
\text { Semarang, Ngaliyan Sub- } \\
\text { district, Semarang Regency }\end{array}$ & Mr. Purbo & $\begin{array}{l}\text { Tuesday until } \\
\text { Saturday }\end{array}$ & $06.30-09.00$ \\
\hline 5 & Online through WhatsApp & Ms. Dian & Tuesday and Saturday & $\begin{array}{l}\text { Cash on } \\
\text { Delivery }\end{array}$ \\
\hline
\end{tabular}

\subsection{The tastes of the consumer society towards Traditional Herbal Drink Ngadirgo Semarang}

\subsubsection{Taste And Texture Of Herbal Drink}

Every community has their own perceptions about the taste of herbal drink. Based on research, each community defines the type of herbal drink Ngadirgo with a distinctive taste. Some of the socalled spices such as bitter taste for pahitan, less bitter for cabe puyang, sweet and sour taste for kunir asam, and sweet taste for beras kencur. However, not all consumers like the taste of certain herbal drinks. Not only that, there are also people who compare the seller of herbal drink Ngadirgo Semarang with other sellers. Herbal drink made by Ngadirgo sellers is sweeter and less thick in texture than other herbals. Consumer's taste regarding the flavor and texture of herbal drinks are very much influenced by individual matters.

\subsubsection{Traditional Herbal Drink Packaging}

The forms of packaging traditional herbal drink Ngadirgo Semarang can be classified into 3 forms, namely plastic, glass and bottles. The three forms of herbal drink packaging are used in the context of practicality of consumers in consuming herbal drink. Herbal medicine is usually consumed still warm (if bought in the morning) and not warm (if bought during the day). The consumers can buy herbal drinks in several packaging, which can be seen in Table 2 as follows.

Table 2. The Packaging and Price of Traditional Herbal Drink Ngadirgo Semarang

\begin{tabular}{clcl}
\hline No & $\begin{array}{c}\text { The } \\
\text { Packaging }\end{array}$ & Size & \multicolumn{1}{c}{ Price } \\
\hline 1 & Plastic & $\begin{array}{c}1 / 4 \mathrm{~kg}(200 \\
\mathrm{ml})\end{array}$ & Rp. \\
& & $2.500,00$ \\
\hline 2 & Glass & $200 \mathrm{ml}$ & Rp. \\
& & & $2.500,00$ \\
\hline 3 & Bottles & $350 \mathrm{ml}$ & $\begin{array}{l}\text { Rp. } \\
\end{array}$ \\
& & & $5.000,00$ \\
\hline
\end{tabular}

\subsection{Perception Of The Consumers About Making Traditional Herbal Drink At Home}

Traditional herbal drink at home personally by the community. Various types of traditional herbal drink are known to the public, such as pahitan, cabe 
puyang, kunir asam, beras kencur, suroh/betel, wejahan, temulawak, and kunir kentel. People usually make traditional herbal drinks based on community needs, in the context of health care or treatment. Homemade traditional herbal drinks are made simply with natural ingredients. Homemade herbal drinks are usually made on a small scale and only for one drink. The tools used are simple according to those at home, like 'Alu'. Currently, the community is still producing homemade herbal drinks for consumption. Usually herbal medicine is produced to treat a disease. The medicinal plants used to make herbal drinks are also relatively easy to find in the surrounding environment or by buying on the market. Some people even deliberately plant medicinal plants around the house. These ingredients such as ginger, kencur, and others.

Knowledge about making traditional herbal drinks is obtained from the process of transmitting knowledge from parents on to their children. Parents pass on their knowledge according to their experiences when making herbal drinks. Traditional herbal drink that is considered practical and easy to make, makes many people make it. Usually someone will make their own herbal drink to cure the disease they are suffering from.

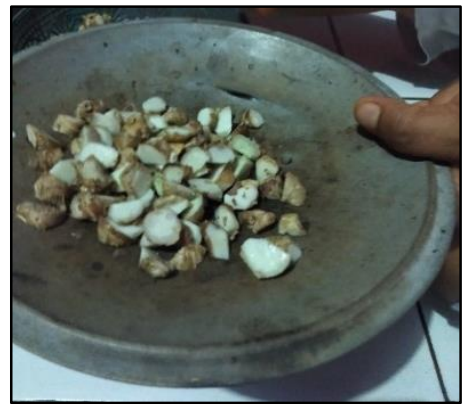

Figure 1. The process of making traditional herbal drink

The making of herbal medicine at home by community groups is not only influenced by the knowledge obtained from parents, but also from the experience process when making herbal medicine. Usually herbal medicine is made based on the need as an ingredient to treat diseases. From complaints of the disease, encouraging someone to make herbal medicine independently because it is easy to make, practically, and can be made at any time. If the herbal medicine is deemed suitable and able to overcome the disease, then they will make the herbal drink. The perception of traditional herbal drink is then passed down to the next generation.

\section{CONCLUSIONS}

The consumer society has various reasons for consuming traditional herbal drinks such as based on perceived disease, side effects of herbal drinking, effectiveness of drinking herbal drink, low prices, and experience of consuming herbal medicine. From this research, it can be seen how consumers perceive traditional herbal medicine Ngadirgo Semarang they consume, including the taste and texture of herbal drink, how to serve it, and the experience of consuming herbal drink. The taste of herbal drinks that consumers like is sweet, bitter, and sour, and the texture is not thick. There are 3 types of serving herbal drinks at Ngadirgo Semarang, namely using plastic, glass and bottles. The community's experience in consuming herbal drink is also inseparable from the community's knowledge of traditional herbal drink which has been passed down from generation to generation.

\section{REFERENCES}

[1] J. Laplante, “Animating Anthropology: On doing Jamu in Java," Med. Anthropol. Theory, vol. 2, no. 2, pp. 125-137, 2017, doi: https://doi.org/10.17157/mat.2.2.190.

[2] WHO, Traditional Medicine in Asia. New Delhi, India: SEARO Regional Publications, 2001.

[3] Departemen Kesehatan Republik Indonesia, UU Nomor 36 Tahun 2009 tentang Kesehatan. 2009.

[4] I. Wijaya, "Socio-cultural Knowledge and Perceptions of Jamu Consumption Risk: Local Wisdom of Urban Javanese Community and Its Relation to the Integration of Traditional Jamu Medicine into Formal Health System in Indonesia," JKM, vol. 11, no. 2, pp. 129-139, 2012.

[5] A. Hidayati and D. A. Perwitasari, "Persepsi Pengunjung Apotek Mengenai Penggunaan Obat Bahan Alam sebagai Alternatif Pengobatan di Kelurahan Muja-Muju Kecamatan Umbulharjo Kota Yogyakarta," Pros. Semin. Nas. “Home Care," pp. 119128, 2011.

[6] H. Jennifer and E. Saptutyningsih, "Preferensi Individu Terhadap Pengobatan Tradisional di Indonesia," J. Ekon. dan Stud. Pembang. Univ. Muhammadiyah Yogyakarta, vol. 16, pp. 26-41, 2015.

[7] M. C. Torri, "Knowledge and Risk Perceptions of Traditional Jamu Medicine among Urban Consumers," European J. Med. Plants, vol. 3, no. 1, pp. 25-39, 2013, doi: https://doi.org/10.9734/ejmp/2013/1813.

[8] J. W. Creswell, Research Design: Pendekatan Metode Kualitatif, Kuantitatif, dan Campuran. Yogyakarta: Pustaka Pelajar, 2016.

[9] L. J. Moleong, Metode Penelitian Kualitatif. Bandung: PT Remaja Rosdakarya, 2017. 